\title{
PERLINDUNGAN HUKUM TERHADAP HAK MILIK ATAS TANAH UNTUK PEMBANGUNAN KEPENTINGAN UMUM
}

\author{
Made Ayu Wangi Utari Suryatika, I Gusti Bagus Suryawan, I Wayan Arthanaya \\ Fakultas Hukum Universitas Warmadewa, Denpasar - Bali, Indonesia
}

\begin{abstract}
Abstrak
Peranan tanah sangat penting selain sebagai modal penyelenggaraan kehidupan benergara namun juga keidupan masyarakat. Tanah berfungsi sebagai pemenuhan kebutuhan manusia dalam berbagai aspek seperti untuk pertanian, perumahan, perkebunan, ataupun kegiatan industry lain. Penelitian ini bertujuan untuk mengetahui bentuk perlindungan hukum terhadap hak milik atas tanah untuk pembangunan kepentingan umum dan mengetahui mekanisme pemberian ganti rugi terhadap hak milik atas tanah untuk pembangunan kepentingan umum. Metode yang digunakan dalam penelitian ini adalah metode penelitian normatif dengan pendekatan koseptual dan perundang-undangan, serta dengan teknik kepustakaan yang dianalisis kuantitatif dalam bentuk deskriptif analitis. Hasil penelitian ini menunjukan bahwa perlindungan hukum terhadap hak milik atas tanah bahwa bentuk perlindungan hukumnya ada dua yaitu perlindungan hukum preventif dan perlindungan hukum represif, selain itu, Pasal 1 angka 10 Undang-undang No. 2 Tahun 2012 merupakan dasar dari pemberian ganti rugi untuk pemegang hak atas tanah. Adapun saran yang dapat disampaikan adalah dalam prakteknya pemegang hak atas tanah sering sekali kurang puas dengan ganti kerugian yang diberikan, dimana menurutnya jumlah ganti kerugian tidak sebanding dengan kerugian materiil dan inmateriil.Maka dari itu diharapkan pemerintah selaku pihak pengadaan tanah berlaku objektif dimana melakukan pertimbangan dan perhitungan yang matang, sehingga ganti kerugian sesuai yang diharapkan oleh pemegang hak atas tanah bahkan nantinya ganti kerugian dapat menjadi ganti untung. Melalui penelitian ini diharapkan kepada pemerintah selaku pihak pengadaan tanah berlaku objektif melakukan pertimbangan dan perhitungan yang matang, sehingga ganti kerugian sesuai yang diharapkan oleh pemegang hak atas tanah bahkan nantinya ganti kerugian dapat menjadi ganti untung.
\end{abstract}

Kata Kunci: Ganti Rugi; Hak atas Tanah; Pengadaan Tanah; Perlindungan Hukum

\begin{abstract}
The role of land is very important in addition to being the capital for administering the life of the state but also the life of the community. Land functions as a fulfillment of human needs in various aspects such as agriculture, housing, plantations, or other industrial activities. This study aims to determine the form of legal protection of property rights on land for the development of public interests and determine the mechanism for compensating land rights for development of public interests. The method used in this study is a normative research method with a conceptual approach and legislation, as well as with library techniques that are analyzed quantitatively in the form of analytical descriptive. The results of this study indicate that the legal protection of property rights to land that there are two forms of legal protection namely preventive legal protection and repressive legal protection, in addition, Article 1 number 10 of Law No. 2 of 2012 is the basis of compensation for holders of land rights. The advice that can be delivered is that in practice land rights holders are often not satisfied with the compensation provided, according to which the amount of compensation is not proportional to material and material losses. Therefore, it is expected that the government as the land acquisition party applies an objective where consideration and careful calculation, so that compensation as expected by the holders of land rights and even later compensation can be compensation. Through this research, it is expected that the government as the land acquisition party objectively applies careful consideration and calculation, so that the compensation according to what is expected by the holders of land rights, even later the compensation can become compensation.
\end{abstract}

Keywords: Compensation; Land Rights; Land Procurement; Legal protection

\section{PENDAHULUAN}

Guna mewujudkan masyarakat yang sejahtera serta adil dan makmur sebagaimana cerminan Pancasila serta Undang-Undang Dasar Negara Republik Indonesia Tahun 1945, masyarakat sangat 
membutuhkan pengadaan tanah guna kepentingan pembangunan.Pembangunan pasar tradisional, jalan raya, pemukiman rakyat bahkan gedung mal merupakan upaya pemerintah untuk mewujudkan pembangunan nasional.Tanah merupakan suatu hak jiika ditinjau dari segi yuridis (Santoso, 2012:9).

Selain hal tersebut di atas, tanah juga dibedakan dalam hal kepentingannya, juga berkaitan dengan sifat kepemilikannya seperti tanah yang digunakan untuk kepentingan umum dan untuk kepentingan pribadi.Terdapat perbedaan konsep atau pengertian kepentingan umum antara UndangUndang Nomor 5 Tahun 1960 tentang Peraturan Dasar Pokok-Pokok Agraria yang memang sebelumnya merupakan landasan hukum soal pertanahan dengan aturan yang terbaru yakni UndangUndang Nomor 2 Tahun 2012 tentang Pengadaan Tanah Bagi Pembangunan untuk Kepentingan Umum, dimana Undang-Undang Nomor 2 tahun 2012, konsep mengenai kepentingan umum hanyalah bentuk legitimasi atau pensahan atas tindakan Negara untuk melakukan pencabutan atau pembebasan tanah orang lain karena hal ini tidak dengan jelas disebutkan dalam aturan. Hal itu termaktub dalam Pasal 18 yang menentukan bahwa untuk kepentingan umum yang mana guna kepentingan bangsa dan negara dan kepentingan bersama dari rakyat, dapat dicabut hak-hak atas tanah seseorang dengan syarat diberikannya ganti kerugian yang layak dan patut dengan cara sebagaimana undang-undang mengaturnya.

Selain dasar hukum tersebut, pengaturan tentang pengadaan tanah diatur dalam Peraturan Presiden No.148/2015 tentang Perubahan keempat atas Peraturan Presiden No.71/ 2012 tentang Penyelenggaraan Pengadaan Tanah Bagi Pembangunan Untuk Kepentingan Umum.Sistem pengadaan tanah untuk kepentingan umum bertujuan untuk memberikan perlindungan hukum kepada masyarakat, sehingga dapat terwujudnya tujuan hukum yaitu keadilan.

Beberapa penelitian telah dilakukan sebelumnya terkait dengan pembahasan saat ini seperti Amalia (2012); Basri (2013); Jayantri, Seputra, \& Suryani (2019); Mengko (2013); Rendrajaya (2018). Dalam hasil penelitian itu menyatakan bahwa imbalan ganti kerugian yang layak dan adil didasarkan atas musyawarah, serta masyarakat dapat mengajukan keberatan terhadap bentuk dan atau besarnya ganti rugi yang diserahkan oleh pemerintah ke Pengadilan Negeri setempat bagi pemegang hak milik atas tanah dalam rangka mendapatkan perlindungan hukum. Berdasarkan deskripsi di atas, maka penelitiaan saat ini bertujuan untuk mengetahui bentuk perlindungan hukum terhadap hak milik atas tanah untuk pembangunan kepentingan umum dan mengetahui mekanisme pemberian ganti rugi terhadap hak milik atas tanah untuk pembangunan kepentingan umum.

\section{METODE PENELITIAN}

Tipe penelitian yang digunakan disini adalah tipe penelitian hukum normatif. Adapun tipe pendekatan permasalahan yang digunakan untuk membahas permasalahan penelitian ini adalah pendekatan perundang- undangan dan pendekatan konseptual, dengan menggunakan penalaran deduktif dan/atau induktif guna mendapatkan dan menemukan kebenaran obyektif.Sumber bahan hukum primer yang digunakan Kitab Undang-Undang Hukum Perdata, Undang - Undang No.2/2012 tentang Pengadaan Tanah Bagi Pembangunan Untuk kepentingan Umum, Undang - Undang No. 5/1960 tentang Peraturan Dasar Pokok Agraria (UUPA), Peraturan Presiden No.148/2015 tentang Perubahan keempat atas Peraturan Presiden No.71/2012 tentang Penyelenggaraan Pengadaan Tanah Bagi Pembangunan Untuk Kepentingan Umum.

\section{HASIL PENELITIAN DAN PEMBAHASAN Bentuk Perlindungan Hukum terhadap Hak Milik atas Tanah untuk Pembangunan Kepentingan Umum}

Perlindungan hukum untuk kepentingan subyek hukum terdapat dua bentuk yaitu perlindungan yang bersifat preventif dan yang bersifat represif. Dapat dikatakan bahwa suatu perlindungan hukum merupakan gambaran dari fungsi hukum sendiri, yang dimana konsepnya bahwa hukum itu diharapkan dapat menjamin suatu keadilan, ketertiban, kepastian, dan kemanfaatan. Menurut Hadjon (1987), perlindungan hukum merupakan suatu bentuk perlindungan terhadap hak asasi manusia serta harkat dan martabatnya sebagaimana diatur oleh aturan hukum itu sendiri. Bentuk perlindungan hukum terhadap masyarakat ada dua hal, yaitu:

a. Perlindungan Hukum Preventif, yaitu bentuk perlindungan hukum dengan mana merupakan bentuk upaya pencegahan, serta diberikannya kesempatan untuk rakyat menutarakan 
pendapatnya. Besar pengaruh perlindungan preventif ini bagi pemerintah, sehingga nantinya pemerintah dapat bersikap hati-hati lagi dalam bertindak.

b. Perlindungan Hukum Represif, yaitu perlindungan hukum yang diberikan setelah terjadinya sengketa atau dengan tujuan penyelesaian dari sengketa tersebut.

Secara harafiah, perlindungan hukum bagi rakyat Indonesia merupakan bentuk implementasi atau penerapan atas prinsip pengakuan serta perlindungan terhadap hak asasi manusia sebagaimana prinsip negara hukum yang berdasarkan pancasila. Dalam realitasnya, praktik pengadaan tanah masih banyak dijumpai diabaikannya hakpemilik tanah terlebih bagi rakyat kecil yang merupakan kaum minoritas. Kepentingan umum dilakukan guna kebutuhan rakyat banyak (Hutagulung, 1985). Penurunan kesejahteraan terjadi sebagai akibat pelepasan ha atas tanah mereka untuk kepentingan yang berdampak besar.Maka hal itu merupakan bentuk pelanggaran terhadap hak asasi manusia yaitu mengenai hak untuk kehidupan yang layak sebagaimana diatur dalam ketentuan konstitusi kita.Maka perlu adanya kajian mengenai pemberian ganti rugi yang pantas untuk pemegang hak katas tanah/pemilik tanah serta kajian mengenai akibat hukum dari adanya konsinyasi ini, sehingga perlindungan hukum terbentuk untuk melindungi hak pemilik atau pemegang tanah, karena tanah yang merupakan unsur penting dalam pembangunan nasional maka pemanfaatannya haruslah dapat mencerminkan kesejahteraan maupun keadilan bagi rakyat (Sumardjono, 2008:41)

Jadi mengingat hal tersebut di atas perlindungan hukum terhadap pemegang hak atas tanah pada dasarnya merupakan poin penting yang seharusnya menjadi perhatian pemerintah sebelum melaksanakan pengadaan atas tanah. Pemerintah harus mengetahui konsekuensi dari rencana tersebut seperti bagaimana cara agar kegiatan pengadaan atas tanah tidak merugikan pihak pemegang hak atas tanah atau pemilik tanah dengan memberikam suatu kompensasi serta hak untuk berdiskusi terkait pengadaan atas tanah. Karena hal tersebut merupakan sarana untuk menghindari konflik dan kesenjangan antara masyarakat dengan pemerintah. Sehingga nantinya pemerintah tidak dianggap semena-mena kepada para pemegang hak atas tanah.Jadi komunikasi merupakan sentral poinnya.

\section{Mekanisme Pemberian Ganti Rugi terhadap Hak Milik Atas Tanah Untuk Pembangunan Kepentingan Umum}

Ganti rugi tidak dapat dipisahkan jika terjadinya pengadaan atas tanah. Karena guna menciptakan keadilan bagi pemegang hak atas tanah ganti rugi diberikan sebagai gantinya, sebagaimana telah ditentukan dalam Undang- Undang No.2 Tahun 2012 pada Pasal 1 angka 10. Ganti kerugian merupakan cara memberikan penghormatan kepada hak serta kepentingan setiap orang yang telah mengorbankan tanahnya untuk kepentingan umum, dapat disebut adil, apabila terjadi keseimbangan antara sebelum dan sesudah pemberian ganti rugi. Guna mewujudkan keadilan bagi pemegang hak, ada baiknya bersikap obyektif dalam menerapkan kriteria dengan standar yang patut terlebih dahulu. Selain itu, penentuan berapa besar baiya ganti kerugian ditentukan melalui musyawarah antara pemilik tanah dengan pihak peerintah yang menginginkan tanah tersebut.Pemberian ganti rugi tidak terbatas pada penggantian nilai dari tanah, melainkan juga dari nilai tanam- tanaman, atau pun bangunan namun termasuk pula secara immaterialdari kerugian yang dapat timbul, seperti kegiatan usahanya, rata-rata jumlah pelanggan sebelumnya akibat perpindahan ketempat lain, berapa jumlah keuntungan yang dapat berkurang.

Pemberian ganti rugi dalam bentuk uang dalam upaya pengadaan tanah, berdasarkan Peraturan Presiden No.148/2015 tentang Perubahan Keempat atas Perpres No 71/2002 tentang Penyelenggaraan Pengadaan Tanah Bagi Pembangunan untuk Kepentingan Umum, dilakukan oleh pihak yang berkepentingan/pemerintah yang memerlukan tanah tersebut berdasarkan data yang telah solid dari pejabat yang ditunjuk untuk itu atau disini ketua pelaksana pengadaan tanah. Selambatnya tiga hari sejak dibuatnya berita acara kesepakatan pemberian ganti rugi harus dilakukan pengecekan data atau validasi. Setelah itu, setidaknya tujuh hari kerja semenjak ditetapkannya jumlah ganti kerugian maka pemberian ganti kerugian harus dilakukan oleh pelaksana. Hasil kesepakatan dalam musyawarah yang telah dilakukan dijadikan dasar untuk pemberian Ganti rugi kepada Pihak yang berhak serta harus dimuat dalam berita acara kesepakatan tersebut. Pemberian Ganti Kerugian pada umumnya haruslah diberikan langsung kepada pemegang hak atau jika tidak pemegang hak karena hukum dapat memberikan kuasanya kepada pihak lain atau ahli warisnya.

Dalam prakteknya mekanisme pemberian ganti kerugian ini dilakukan dengan cara, yaitu 1) Instansi pemerintah yang berkepentingan membuat daftar nominatif pemberian ganti rugi berdasarkan 
hasil pengecekan menyeluruh yang diumumkan panitia atau keputusan panitia mengenai bentuk maupun besarnya jumlah ganti kerugian atau berdasarkan keputusan gubernur yang bersifat menetapkan ataupun mengadendum keputusan panitia atau keputusan gubernur mengenai perubahan besar ganti rugi ataupun bentuk ganti ruginya. 2) Pembayaran ganti kerugian dilakukan langsung di lokasi yang telah ditentukan panitia jika dalam bentuk uang, harus disaksikan oleh setidaknya 3 orang anggota panitia. Selain itu, dalam berita acara pemberian ganti rugi, besar ganti rugi perlu dicatatkandannantinya ditandatangani oleh penerima bersama dengan ketua/wakil panitianyadengan setidaknya 2 orang anggota panitia dengan selalu meminta tanda penerimaan.

Selanjutnya, pihak yang berkepentinganmelakukan pengajuan pelaksanaan pengadaan tanah kepada Lembaga Pertanahan, setelah ditetapkannya lokasi pembangunan.Maka para pihak harus mengalihkan tanahya melaui Lembaga Pertanahan.Pemberian ganti rugi dan pelepasan hak tanah merupakan bentuk peralihan hak yang dilakukan. Perlu diketahui bahwa pelaksanaan pengadaan tanah bagi kepentingan umum ini meliputi:

1. Inventarisasi sertamengidentifikasi atau mendata mengenai pemilikan, penguasaan, pemanfaatan dan penggunaan tanah: Pertama yaitu pemetaan serta pengukuran tanag bidang per bidang, dan Kedua yaitu pengumpulan objek pengadaan dan data para pihak. Penilaian ganti kerugian dilakukannya penilalian oleh penilai bidang perbidang terkait besarnya nilai ganti kerugian yang ditetapkan oleh Lembaga Pertanahan, meliputi bangunan, tanah, benda yang terkait dengan tanah di ruang atas dan bawah tanah, tanaman kerugian lain yang dapat dinilai.

Besarnya nilai dari ganti kerugian yang digunakan merupakan hasil penilaian yang telah disampaikan pada Lembaga Pertanahan yang diakukan pada saat diumumkannya penetapan lokasi pembangunan untuk kepentingan umum. Setelah itu, nilai ganti kerugian ini dijadikan dasar dalammusyawarah untuk penetapan jumlah ganti kerugian.

2. Musyawarah penetapan ganti kerugian

Musyawarah dilakukan Lembaga Pertanahan dengan pihak pemilik tanah setidaknya batasnya selama 30 hari kerja sejak hasil penilaian disampaikan. Hasil kesepakatan inilah dijadikan dasar pemberian ganti kerugian kepada pihak pemilik tanah serta tentunya haruslah dimuat dalam berita acara kesepakatan.

3. Pemberian ganti kerugian

Pihak pemilik tanahsetelah diberikannya ganti kerugian harus melepaskan tanahnya secepatnya.Pihak yang berhak menerima ganti kerugian juga wajibmenyerahkan bukti kepemilikan tanah yang mana merupakan objek dari pengadaan tanah.Pelepasan hak ini bertujuanuntuk memutuskan hubungan hukum dari pihak yang berhak atas tanah kepada negara melalui Lembaga Pertanahan.Proses pelepasan inidieksekusi atau dilakukanpaling tidak selambat- lambatnya selama 60 hari kerja sejak penetapan lokasi pembangunan. Apabila belum selesai sesuai jangka waktu tersebut, maka dinyatakan tanah tersebut telah dilepaskan dan menjadi milik instansi pemerintah yang membutuhkan atau Negara dan dapat dilakukan pembangunan secepatnya. Siapapun yang tidak melaksanakan ketentuan tersebut akandikenai sanksi berupa sanksi administratif sesuai dengan ketentuan peraturan perundang-undangan yang berlaku.

Pada hakikatnya, setiap orang tidak ada yang mau rugi, maka karena hal tersebut para pemegang hak atas tanah haruslah diperhatikan hak-haknya atas penggantian kerugian yang sesuai dan patut. Dengan melakukan upaya ganti rugi yang mana jumlahnya sesuai serta patut sehingga diterima oleh pemilik tanah, maka konflik akan terhindari. Seringkali terjadi ketidakpuasan mengenai nilai ganti kerugian antara pemerintah dengan pemilik tanah atau pemeganh hak atas tanah dikarenakan tidak adanya kesepakatan para pihak serta pihak yang satu dengan yang lainnya memiliki tuntutan tersendiri serta standar tersendiri dalam menetapkan nilai ganti rugi. Untuk memfasilitasi hal tersebut, diskusi sehat serta kemampuan bernegosiasi diperlukan, sehingga para pihak tidak merugi. Untuk itu para pemegang hak atas tanah atau pemilik tanah dapat melepaskan tanahnya untuk digunakan sebavai fungsi sosial, yang mana tujuannya juga untuk kesejahteraan masyarakat, sebagaimana konstitusi menginginkannya.

\section{SIMPULAN DAN SARAN}

\section{Simpulan}

Perlindungan hukum merupakan bentuk jaminan untuk rakyat guna terciptanya tujuan hukum itu sendiri. Bentuk perlindungan hukum terhadap masyarakat ada dua hal, yaitu: Perlindungan Hukum 
Preventif, yakni bentuk perlindungan hukum berupa pencegahan atau dilakukan sebelum suatu sengketa atau konflik terjadi. Selanjutnya, Perlindungan Hukum Represif, yakni bentuk perlindungan hukum dimana lebih ditujukan dalam penyelesaian sengketa. Sehingga tujuan dari perlindungan hukum preventif adalah mencegah terjadinya sengketa sedangkan perlindungan hukum yang represif bertujuan untuk menyelesaikan sengketa. Maka upaya tersebut dapat menjamin perlindungan maupun jaminan penghormatan terhadap hak-hak pemegang hak atas tanah, karena tanah yang merupakan komponen vital sehingga penggunaanya harus dapat mewujudkan serta menciptakan kesejahteraan dan keadilan bagi seluruh rakyat. Sebagai upaya penghormatan kepada hak pemilik tanah yang mau melepaskan hak atas tanahnya guna kepentingan umum, diberikan suatu ganti rugi yang patut. Beberapa mekanisme pemberian ganti rugi dilakukan dengan cara, pertama, instansi pemerintah yang memerlukan tanah membuat daftar nominatif pemberian ganti-kerugian berdasarkan keputusan panitia mengenai bentuk dan besarnya ganti kerugian atau keputusan gubernur yang bersifat mengukuhkan atau mengubah keputusan panitia atau keputusan gubernur mengenai revisi bentuk dan besarnya ganti-kerugian. Pembayaran ganti kerugian dalam bentuk uang dilakukan secara langsung di lokasi yang ditentukan oleh panitia, dengan disaksikan oleh sekurang-kurangnya 3 orang anggota panitia. Selain berupa uang, ganti kerugian dituangkan dalam berita acara pemberian ganti kerugian yang ditandatangani oleh penerima ganti kerugian yang bersangkutan dan ketua atau wakil ketua panitia serta sekurang- kurangnya 2 orang anggota panitia. Selanjutnya yang perlu dicermati ialah bahwa pemberian ganti kerugian dalam bentuk uang dibuktikan dengan tanda penerimaan.

\section{Saran}

Berdasarkan Pasal 6 Undang-undang Pokok Agraria semua hak atas tanah memiliki fungsi sosial, sebagaimana ditegaskan yaitu: "Semua hak atas tanah mempunyai fungsi sosial". Asas tersebut berarti bahwa jika Negara menginginkan tanah milik seseorang guna kepentingan yang berdampak besar atau untuk umum maka pemegang hak atas tanah harus mampu melepaskan hak atas tanahnya kepada Negara atau pemerintah (Sahnan, 2016:82). Walaupun tanah dikatakan memiliki fungsi sosial, namun kepentingan para pemegang hak atas tanah harus tetap diberikan jaminan serta perlindungan hukum, itu dikarenakan pemilik tanah memiliki hak mutlak terhadap tanahnya sendiri, jika sewaktu-waktu pemerintah ingin melakukan pengadaan tanah maka pemilik tanah harus merelakan tanahnya, disinilah diperlukan jaminan perlindungan hukum untuk melindungi hak-hak kepemilikan tanah. Kemudian, dalam prakteknya pengadaan tanah untuk kepentingan umum ini sering sekali menimbulkan perselisihan antara pihak pemegang hak atas tanah dengan pihak pengadaan tanah khususnya mengenai bersar ganti kerugian yang akan diberikan. Pemegang hak atas tanah sering sekali kurang puas dengan ganti kerugian yang diberikan, dimana menurutnya jumlah ganti kerugian tidak sebanding dengan kerugian materiil dan inmateriil. Maka dari itu diharapkan pemerintah selaku pihak pengadaan tanah berlaku objektif dimana melakukan pertimbangan dan perhitungan yang matang, sehingga ganti kerugian sesuai yang diharapkan oleh pemegang hak atas tanah bahkan nantinya ganti kerugian dapat menjadi ganti untung.

\section{DAFTAR PUSTAKA}

Amalia, R. (2012). Perlindungan Hukum Bagi Pemegang Hak Atas Tanah Dalam Penetapan Ganti Rugi Terkait Dengan Pengadaan Tanah Untuk Kepentingan Umum. Yuridika, 27(3), 267-280.

Basri, H. (2013). Pemegang Hak Atas Tanah Dalam - Justice and Legal Certainty for Land Title Holders in. IUS: Kajian Hukum Dan Keadilan, 1(1), 77-93.

Hadjon, P. M. (1987). Perlindungan hukum bagi rakyat di Indonesia: sebuah studi tentang prinsipprinsipnya, penanganannya oleh pengadilan dalam lingkungan peradilan umum dan pembentukan peradilan administrasi negara. Surabaya: PT. Bina Ilmu.

Hutagulung, A. S. (1985). Program Redistribusi Tanah di Indonesia: Suatu Sarana ke Arah Pemecahan Masalah Penguasaan Tanah dan Pemilikan Tanah. Jakarta: Rajawali Pers.

Jayantri, A. A. D., Seputra, I. P. G., \& Suryani, L. P. (2019). Perlindungan Hukum terhadap Pemegang Sertipikat Hak Milik atas Tanah yang Mengalami Sengketa Kepemilikan. Jurnal Analogi Hukum Journal, 4(2), 137-142.

Mengko, B. (2013). Perlindungan Hukum Terhadap Pemegang Hak Milik Atas Tanah Pembangunan. Lex Privatum, 1(5), 29-38.

Rendrajaya, K. A. B. (2018). Pengaturan Hak Milik Atas Tanah Yang Dialihkan Untuk Kepentingan 
Umum Perspektif Perlindungan Pemilik. Jurnal Kertha Patrika, 40(1), 37-44.

Sahnan. (2016). Hukum Agraria Indonesia. Malang: Setara Press.

Santoso, U. (2012). Hukum agraria: Kajian Komprehensif. Jakarta: Kencana.

Sumardjono, M. S. . (2008). Tanah dalam perspektif hak ekonomi, sosial, dan budaya. Jakarta: Kompas.

Undang-Undang Nomor 5 Tahun 1960 Tentang Dasar dan Pokok-Pokok Agraria

Undang-Undang Nomor 2 Tahun 2012 Tentang Pengadaan Tanah Bagi

Pebangunan Untuk Kepentingan Umum 